\title{
Los escoceses de Indias y el Testamento de su Católica Majestad
}

\author{
Julio ARroyo Vozmediano \\ UNED*
}

\section{The scots of the Indies and the will of his catholic majesty}

\begin{abstract}
RESUMEN
Entre los años 1698 y 1700 los escoceses

intentaron establecer un enclave comercial en el Darién que integrara el tráfico de esclavos de África con las rutas

a Asia y Europa. No consiguieron su propósito y, tras diversas peripecias, fueron desalojados por una expedición armada conducida por el gobernador de

Cartagena de Indias, don Juan de la

Pimienta. Su aventura coincidió en su desarrollo con la negociación de los

tratados de partición y con la cuestión sucesoria española. Este estudio sostiene que la colonia es un elemento importante para la comprensión del cambio dinástico.

Primero, su desarrollo también coincidió con - y fue un aspecto más de - la grave crisis diplomática entre Inglaterra y

España durante los meses clave del proceso sucesorio. Además, perjudicaba a la candidatura de los Austria de Viena al demostrar las carencias de su opción en caso de un conflicto en América. Por último, la reacción que se produjo en Madrid debe de ser vista como un elemento más de la respuesta española al tratado de partición de Londres de 1700.
\end{abstract}

\begin{abstract}
Between 1698 and 1700 the Scots attempted to establish a trading post in Darien to integrate the African slave traffic with Asia and Europe's commerce. They failed their purpose and, after various vicissitudes, were evicted by an armed expedition led by the governor of Cartagena de Indias, Don Juan de la Pimienta. Their adventure coincided in its unfolds with the negotiation of the treaties of partition and the Spanish succession issue. This study argues that the colony is an important element for the dinastic change's understanding. First, its development also coincided with - and was one aspect of - the diplomatic crisis between England and Spain during the key months of the succession process. Also harmed the Viennese Austria's candidacy to demonstrate the shortcomings of its choice in the case of a conflict in America. Finally, the reaction that occurred in Madrid should be seen as one element of the Spanish response to the partition's Treaty of London of 1700.
\end{abstract}

* Este trabajo ha sido elaborado gracias a la ayuda de los proyectos financiados por el Ministerio de Economía y Competitividad «Comercio y Finanzas Internacionales en una España en Transición, 16801721» (HAR 2011-25907) y «Conservación de la Monarquía y Equilibrio Europeo entre los siglos XVII y XVIII» (HAR 2012-37560-C02-01). 


\section{PALABRAS CLAVE}

Darién, Carlos II, Guillermo III, Sucesión

Española, Tratado de Partición de 1700,

Escocia, España, Inglaterra.

\section{KEY WORDS}

Darién, Charles II, William III, Spanish

Succession, Partition Treaty of 1700,

Scotland, Spain, England.

Old pirates, yes, they rob I, sold I to the merchant ships, minutes after they took I from the bottomless pit But my hand was made strong by the hand of the Almighty We forward in this generation triumphantly. BOB MARLEY \& THE WAILERS, Redemption Songs, Uprising, Londres, Island Records, 1980.

\section{LA AVENTURA ESCOCESA}

Cualquier idea que implique la edificación de una nueva sociedad al otro lado del océano, combinará elementos utópicos con aquéllos propios de las acciones atrevidas. El plan escocés en el Darién los integraba en un esquema de tipo comercial que buscaba, además, la redención de la propia Escocia en una misión que aportaba un nuevo proyecto de país. Sin embargo, y a pesar del indudable interés del episodio, el presente artículo no versará sobre la colonia escocesa, sino sobre como influyó en el desarrollo político europeo, remitiéndonos para la aventura en sí misma, a la amplia bibliografía sobre ella1. No obstante, vamos a trazar un breve resumen de la misma, para facilitar la exposición posterior de nuestro estudio.

Escocia compartió soberano con Inglaterra desde 1603, cuando Jacobo Estuardo sucedió en el trono a Isabel I. El avance del siglo XVII fue un periodo difícil para el reino septentrional británico, marcado por un contexto de tensiones civiles, religiosas y políticas. Carente de cualquier participación significativa en el comercio internacional, se fue abriendo paso, como método de luchar contra su languidecimiento, la idea de desarrollar una expansión colonial que estimulara la estabilidad social y el crecimiento económico del país ${ }^{2}$. The Company of Scotland Trading to Africa and the Indies buscaba el establecimiento de un asentamiento permanente en el Darién, una región poco habitada del Istmo de Panamá. Su modelo incluía el establecimiento de colonos, la plantación de cultivos y un desarrollo comercial que, organizando el traslado de mercancías de Oriente desde el Pacífico, se configurara como vértice de un triángulo comercial que incluiría a Europa y África. Inspirada en la compañía de las Indias Orientales, recibió su carta de naturaleza mediante un Acta del Parlamento de Edimbur-

\footnotetext{
1 Resulta imprescindible hacer referencia - en primer lugar- a las recopilaciones de documentos de las colecciones de HILL BURTON, 1849. SCOTT y JOHNSTON, 1906, que fueron complementadas posteriormente por otra de PRATT INSH, 1924. También cabe el citar las monografías de BARBOUR, 1907, la de HART, 1930; las de PRATT INSH, 1932 y 1947, así como la más reciente de PREBBLE, 1969. Citamos también varios trabajos recientes que tratan directamente diversos aspectos del asunto: ARMITAGE, 1995, 97/118. HIDALGO (Albuquerque, 2001): 311/350. DOBSON, 2005, 114/122, y por último destacamos, muy especialmente, el trabajo de STORRS, Londres, 1999): 5/38, que trata el episodio desde una «perspectiva» española prestando atención a la eficacia de la respuesta, al significado que se dio en la corte de Madrid a la tentativa escocesa y que tiene el mérito de haber apuntado a su influencia en la Cuestión Española.

2 Véanse, LEVACK, 1987. ALLAN (Cambrigde, 1995): 242/263. RILEY, 1979.
} 
go de 26 de junio de 1695. Ésta le reconocía privilegios comerciales en Escocia y un monopolio comercial con África y con América, fijándose un objetivo de capital de 600.000 libras que habrían de ser reunidas, a partes iguales, entre inversores de Escocia y de Londres ${ }^{3}$.

Planteada como una compañía por acciones, su creación deriva de la iniciativa del financiero lowlander William Paterson ${ }^{4}$. Éste, después de haber sido uno de los promotores y primeros directivos del recién creado Banco de Inglaterra (1694), regresa a Edimburgo, donde participa en la creación del Banco de Escocia (1695) y promueve distintos negocios. Paterson parecía el hombre adecuado para impulsar el proyecto escocés, gracias a sus relaciones en la City. Efectivamente, pronto se consiguieron los compromisos sobre la mitad del capital en Londres.

Sin embargo, los directivos de la Compañía de las Indias Orientales, quienes sintieron sus intereses amenazados por el plan, y Guillermo III, consciente del potencial negativo que la iniciativa escocesa proyectaba sobre sus relaciones con España, consiguieron que los inversores londinenses retiraran sus compromisos de suscripción de capital. Ante esto, en vez de suspender la operación, se redujo el objetivo de capital a 400.000 libras, que fueron reunidas en Escocia, en medio de un enfervorecido sentimiento patriótico ${ }^{5}$. Se calcula que dicha cifra representaba la mitad de la riqueza nacional. Con este capital suscrito, se hicieron los preparativos y una primera expedición salió del puerto de Edimburgo, Leith, en julio de 1698 con 1.200 colonos a bordo, entre los que se viajaba el propio Paterson. Sólo unos pocos de los que la integraban sabían el destino concreto del viaje, que no fue comunicado hasta dejar atrás Madeira. Llegaron, con 70 bajas producto de la travesía, a la desembocadura del río Darién, en Panamá. Allí fundaron Nueva Edimburgo, establecieron su colonia y edificaron un fuerte.

La región, primer establecimiento en el continente, había sido abandonada por los españoles en la primera mitad del siglo XVI debido a las difíciles condiciones de habitabilidad de la región. La misma se encontraba prácticamente deshabitada, a excepción de algunos indios Kuna. Los escoceses entraron en contacto con ellos, tratando de atraérselos, aunque no consiguieron los resultados esperados ${ }^{6}$ Tras algún éxito inicial, el clima, las bajas por las enfermedades tropicales y las escaramuzas, el hambre provocada por la falta de provisiones fueron minando su determinación. Finalmente las noticias sobre una gran expedición que se estaba preparando para desalojarlos provocaron que los supervivientes abandonaran la colonia, en julio de 1699. Un segundo contingente escocés partió en agosto, esta vez desde el Clyde, poco antes desde que llegaran noticias del primer fracaso. Encontraron el asentamiento desierto, pero lo volvieron a ocupar en noviembre de

3 PRATT INSH (Edimburgo, 1924), págs. 288-295.

4 ARMITAGE (Londres, 1994): 5/10. STEEL (Oxford, 1896): 260/281. FORRESTER, 2004; PRATT INSH (Edimburgo, 1928): 241/254.

5 WATT (Edimburgo, 2005): 97/118.

6 McPHAIL (Durham, 1994): 129/147. 
ese año. Algunos de los supervivientes de la primera expedición retornaron desde las colonias inglesas de América reuniéndose con el segundo contingente.

La reacción de las autoridades españolas de América y de Madrid fue razonablemente rápida 7 . Se organizaron expediciones con recursos y con tropas de los virreinatos de Perú y Nueva España y desde la metrópoli. Una primera expedición, dirigida por el presidente de Panamá, conde de Canillas, salió desde Cartagena de Indias en enero de 1699. Regresó, sin haber conseguido desalojar a los escoceses, después de algunas escaramuzas, debido a las lluvias de primavera y a las dificultades tanto de la marcha por tierra, como para la navegación de los barcos que los acompañaban.

Después de este primer intento de desalojo, se iniciaron los preparativos para una segunda expedición desde Cartagena de Indias, con recursos de los virreinatos de Perú y de Nueva España. Las noticias de dichos preparativos fueron las que provocaron el primer abandono escocés y éste su suspensión. Mientras tanto, desde España, se había enviado algunas tropas con un nuevo gobernador de Cartagena, Juan de la Pimienta, quien, al conocer el segundo asentamiento, retoma los planes y fue quien consiguió la capitulación definitiva de los colonos en abril de 1700. Mientras tanto, en Cádiz, ante la nueva tentativa escocesa, se preparaba una nueva flota expedicionaria mucho más seria y nutrida bajo la comandancia de Pedro Fernández de Navarrete.

Los motivos del fracaso escocés que se han señalado tanto por sus contemporáneos, como por la historiografía son diversos: las características y el clima del territorio elegido, las dificultades de un desarrollo colonial escocés sin un apoyo decidido de Inglaterra, la deficiente organización, la falta de previsión de la respuesta española, pero, en cualquier caso, se trató de un desastre sin paliativos ${ }^{8}$. Las pérdidas fueron cuantiosas: humanas, económicas y, a la postre, políticas. $\mathrm{E}$ propio reino se vio enfrentado a la quiebra por un asunto en el que se había perdido la mitad de la riqueza nacional y que terminó siendo utilizado como un argumento fundamental en la unión de $1707^{9}$.

\section{LONDRES}

El tiempo durante el que se estaba desarrollando la aventura escocesa fue uno de los más complicados del reinado de Guillermo III ${ }^{10}$. La división política en

\footnotetext{
7 Sobre los aspectos militares de la aventura, nos hemos guiado por STORRS (Londres, 1999): 5/38.

8 Para ilustrar las dificultades del viaje de la primera expedición, en relato de un protagonista, véanse: WALLACE (Londres, 1700/1701): 536/543. Un apunte sobre las dificultades del establecimiento en esta concreta zona, WARD (Durham, 1989): 691/713. PIQUERAS CÉSPEDES (Barcelona,, 1998): $211 / 223$.

9 Sobre este particular, véase, SMOUT (Glasgow, 1964): 455/467, referencias en págs $461 / 466$ y KEITH (Oxford, 1909): 44/60. Sobre los factores de la unión, puestos en relación con la Sucesión Española, resulta imprescindible consultar el trabajo de STORRS (Edimburgo, 2008): 31-44.

10 Passim: COWARD, 2003, 356/359. McJIMSEY (Boone, 1991): 61/74. HORWITZ, 1968. Las dificultades económicas y financieras de Guillermo III, y su encaje constitucional, se pueden seguir en REITAN (Oxford, 1970): 571/588.
} 
Londres había propiciado una alianza entre sectores tories y whigs unidos en el llamado New Country Party ${ }^{11}$. Éste había desarrollado, desde la comisión de cuentas públicas, un estricto programa político de control y oposición a las políticas de la Corona y de ataque al gobierno de los Junto Lords ${ }^{12}$. El mismo se encontraba centrado en la inspección de las prácticas que entrañaban un cierto riesgo de corrupción y de arbitrariedad del gobierno: los placemen, las concesiones de tierra en Irlanda, la presencia de extranjeros en los oficios de gobierno y en la polémica sobre el ejército permanente ${ }^{13}$.

De estos asuntos había dos que atañen indirectamente al contenido de estas páginas, el debate sobre el ejército permanente y los consejeros extranjeros del rey. Sobre todo la primera de ellas se tradujo en una situación de debilidad del rey de Inglaterra, pendiente de las negociaciones de partición con Luis XIV. El Country conseguía imponer sus puntos de vista en el Parlamento, limitando en 1697 el ejército a diez mil soldados, un tercio de los existentes ${ }^{14}$. El año siguiente, con el retroceso de los Junto en las elecciones, se redujo esa cifra a siete mil, que debían ser ingleses de nacimiento, ante la constancia de que se había priorizado el conservar los regimientos formados por tropas extranjeras, lo que conecta con el asunto de los extranjeros. Por último, en la primavera de 1699 obligaba a Guillermo III a enviar al continente a sus apreciados Blue Guards holandeses. Paul Monod cuenta que «During the summer, they were followed by a procession of tory politicians, going not to Holland, but to St Germain " ${ }^{15}$. Y éste asunto, el de la pervivencia de la amenaza jacobita, es muy importante. Guillermo III debía de tenerlo

11 Passim: HAYTON, 1984, 37/85. WALCOTT, 1956, 92/93. HORWITZ (Cambrigde, 1966): 45/69; 1969, 96/115; (Cambrigde, 1971): 77/89. (Londres, 1974):36-53. SNYDER (Londres, 1972): 38/73; BURTON, RILEY y ROWLANDS, 1968; RUBINI (Boone, 1978): 193/208 y 1968.

12 Respecto a la comisión de cuentas públicas, resulta imprescindible el trabajo de DOWNIE (Oxford, 1976): 33/51. En el mismo se puede seguir en el mismo la creación e inicios de la comisión y se trata de un trabajo muy serio e interesante sobre como ya desde los inicios de la comisión se fueron tejiendo los lazos entre los comisionados que darían lugar a un programa de control del gobierno. En palabras del autor, la comisión no fue obra del New Country Party sino éste consecuencia de aquella (pág. 51). Referencias sobre la importancia de la comisión en McJIMSEY (Boone, 1999): 561/563; RUBINI (Boone, 1978): 206. HARRIS, 1993, 164. COWARD, 2003, 374/376 y 382/383. Los antecedentes del ascenso de los Junto Lords en McJIMSEY (Boone, 1999): 560/572. Sobre la formación de los Junto, HOLMES (Londres, 2009): 100/114. COWARD, 2003, 380/383. Un relato de la decisiva influencia del conde de Sunderland en estos acontecimientos y en la promoción de los Junto Lords, en KENYON (Oxford, 1956): $576 / 602$.

13 Sobre el ejército permanente, véase SCHWOERER (Cambrigde, 1966): 74/94. En este artículo se puede seguir toda la evolución de este asunto. Más sobre el debate sobre el Standing Army, en HUMPHREY y HANSEN (Cambridge, 2010), 243/259. SCHWOERER (Berkeley, 1965): 187-212. SNYDER (Berkeley, 1967): 241/271. HAYTON (Londres, 1987): 141/163. La polémica sobre los placeholders, en FOORD (Oxford, 1947): 484/507. También se encuentran referencias en RUBINI (Boone, 1978): 193/198 y 204. NAAMANI TARKOW (Oxford, 1943), 548/550. HOPPIT, 2000, 44, 165 y 409. Las Irish forteitures en DOYLE (Dublín, 1997): 28/59. BERGIN (Dublín, 2004): 9/36. O’SULLIVAN (Dundalk, 1992): $430 / 445$. STEELE (Williamsburg, 1966): 596/619. Por último, respecto a los foreign advisors, véase COWARD, 2003, 386. CHREE O'MALLEY (Boone, 1976): 333/350. ONNEKINK, 2004, 111/119.

14 Véase CHILDS, 987, cap. viii, «The Great Disbandment», 184/208.

15 Véase Paul MONOD (Oxford, 1987): 289/310, cita en 306. 
especialmente presente, sobre todo en una materia que implicaba a Escocia, uno de los bastiones del irredentismo jacobita ${ }^{16}$.

Efectivamente, la debilidad del rey derivada de la pérdida de fuerza militar debe ser contemplada junto a la presencia de su antecesor en Saint Germain, que intentaría incluir durante las conversaciones del Tratado de la Haya ${ }^{17}$. Guillermo III buscaba neutralizar el peligro que representaba su suegro logrando su expulsión de Francia, preferiblemente a las Provincias Unidas, donde quedaría bajo su control, o al menos alejarlo aun más de Inglaterra ${ }^{18}$. Al final de dichas negociaciones, cuando se le hace un requerimiento expreso sobre este particular, Luis XIV rechazará desalojar a Jacobo de Saint Germain, alegando razones de prestigio personal ${ }^{19}$.

Tanto el ejército permanente como el asunto de los extranjeros tuvieron una notable repercusión pública. La producción de panfletos y la publicación de noticias en la prensa de Londres se desenvuelven en este tiempo dentro de un marcado tono patriótico y, a veces, xenófobo ${ }^{20}$. Esto estaba fundamentalmente dirigido contra los consejeros holandeses, pero alcanzaba a los hugonotes emigrados, a la Francia de Luis XIV o incluso a los españoles, quienes no se vieron libres de estos ataques.

\section{LOS ESCOCESES EN EL DARIÉN}

Desde la primavera de 1699 se habían empezado a hacer notar sus consecuencias en las relaciones anglo-españolas ${ }^{21}$. En una de sus primeras comunica-

${ }_{16}$ Para una visión de conjunto del jacobitismo, proponemos el libro de LEMMAN, 1995, y sus págs. 28/106, para el periodo tratado en este trabajo. También sobre este tema, véanse SZECHI (Oxford, 1993): 610/628. JONES (Oxford, 1994): 52/73. CRUICKSHANKS y ERSKINE-HILL (Cambrigde, 1985): 358/365. CHRISTIE (Oxford, 1987): 921-931.

17 «Par malheur, les bons procédés de Guillaume III n'avaient au fond qu'un motif et qu'un but fort égoïstes: obtenir que Louis XIV expulsât du château de Saint-Germain le fantôme royal qui hantait ses insomnies et qui, légalement, s'appelait toujours Jacques II Aussi la première démarche de Portland devaitelle viser à un ordre d'exil. Peut-être du reste une circonstance toute fortuite contribua-t-elle à faire sortir l'ambassadeur britannique de sa réserve professionnelle. Le lundi 17 février, en venant à l'audience du Roi, il rencontra dans les appartements de Versailles lord Middleton, premier ministre in partibus du souverain détrôné, et qui, malencontreusement, était venu de Saint-Germain ce jour-là", en LEGRELLE, 1889, 275.

18 Se pueden seguir las conversaciones respecto a este asunto durante el primer proceso de negociación en LEGRELLE, 1889, 263/264, 275/277, 302, 309, 330 y 595 y en GRIMBLOT, 1848, 24, 183/187, 191,198 y 201/205.

19 Ibid. 203/204.

20 La influencia de este periodo en la formación de un patriotismo inglés, en ARMITAGE (Cambrigde, 1997): 397/418, referencias en 408. Cabe destacar la brillante y mordaz defensa que Daniel Defoe hizo de Guillermo III en «The True-Born Englishman» (1701), en donde defendía el carácter aluvial de la nación inglesa, en respuesta al panfleto atribuido al whig radical John Tutchin, «The Natives: an answer to The foreigners». Sobre este tema, LÓPEZ CAMPILLO, 2008, 262/263. También Tallard se hacía eco en su correspondencia de esta polémica, por ejemplo el 12/I/1699, escribía a Luis XIV: «What I learn of the Parliament induces me to believe that the House of Commons will not relax in favour of foreigners; the Court party not having ventured to speak yesterday», GRIMBLOT, 1848, 331.

21 La primera crónica sobre la aventura escocesa la había recibido Stanhope desde Holanda, cuando todavía no se conocía en Madrid, véase Lord MAHON, 1744, 156. 
ciones a Londres sobre esta materia, el enviado Stanhope expresa la preocupación que existe en Madrid por las Indias y el establecimiento escocés allí, haciendo especial hincapié en la presencia de ministros heréticos. Informa de que se habían mandado órdenes a América de no recibir a «nuestros» barcos en sus puertos, ni proporcionarles agua fresca, ni establecer trato con los colonos ${ }^{22}$. Unos días más tarde remite informaciones sobre un memorial presentado por el embajador francés en Madrid, que le preocupa e insiste en lamentarse de que el proyecto se hubiera emprendido:

«He certainly designs to break a quarrel between England and Spain in the Indies, and in that case has undoubtedly promised his master assistance to Spain against us, which should be an enclearment to these people as extremely to facilitate his being received as successor to the Monarchy, and exclude us as being enemies from any share in the disposal of it» ${ }^{23}$.

Unas semanas más tarde, informaba a Londres de una resolución de la corte de Madrid de emplear a todos los hombres disponibles para expulsar a los escoceses de su asentamiento ${ }^{24}$. En su contestación, el secretario Vernon le comunica que no han sabido nada del embajador español relativo a este asunto, que atribuye a una iniciativa exclusivamente escocesa, que somete a una presión peligrosa la posición inglesa y, además, tacha a los colonos del Darién de visionarios y poco fiables ${ }^{25}$.

En abril Stanhope había escrito al secretario de Estado Vernon para comunicarle que el conde de Oropesa había sido desterrado de Madrid. El diplomático se lamentaba de ello ya que Oropesa era «irreconciliable con los intereses franceses». En este mismo documento se hace también referencia a la aventura escocesa. Dice el diplomático inglés que, aunque no cree que mucha gente en Madrid esté al corriente de este asunto, el rey lo conoce y que ha sabido de su profundo

22 La preocupación por los misioneros escoceses en The National Archives State Papers (en adelanteTNA SP) 9474 fol. 144. Stanhope al secretario Vernon, 13/III/1699. Los alegatos jurídicos españoles en BL Mss Add 28,943Folios 223 a 226. «Spanish Reasons against the Scotch Invasion of Darien send to his $\mathrm{Maj}^{\mathrm{ty}}$ » memorial en ingles, explicando las razones para oponerse a la invasión, siendo la principal su afirmación sobre el derecho de soberanía que le asistía sobre esas tierras, que la ocupación se había producido en época de paz y constituía una ruptura de la ley de las naciones. Se puede ver el seguimiento del manifiesto en la prensa en Post Boy, 5/X/1699, $\mathrm{n}^{\circ} 702$ y Post Man and the Historical Account, 5/X/1699, $n^{\circ}$ 666. También se recoge en Post Boy, 14/X/1699, $\mathrm{n}^{\circ}$ 706, con noticias de Madrid, y que incluye el apoyo de la santa Sede a los Derechos españoles. Según este ejemplar, el rey había agradecido el apoyo recibido del Papa a los derechos españoles en tierra firme.

23 TNA SP 9474 fol. 145. Stanhope al secretario Vernon, 18/III/1699. En parecidos términos escribe a su colega de Lisboa, Methuen, mostrando como el embajador francés ha remarcado las aristas religiosas del asunto: "The French Ambassador has represented in writing great danger the Spaniards are in of losing their by the great number of English Scotch and lately gone thither and that they seem also to a design to destroy the Catholic religion there carried over several hundred heretic ministers to that purpose which his Master thought very to acquaint his Catholic Majesty and that speedy course might be taken to prevent it«, Lord MAHON, 1744, 158.

24 TNA SP 9474 fol. 146. Stanhope al secretario Vernon, 15/IV/1699.

25 TNA SP 9474 fol. 148-150. El secretario Vernon a Stanhope, 18/IV/1699 (O.S). Las instrucciones de Stanhope sobre este asunto, en Lord MAHON, 1744, 159/160. 
desagrado por él ${ }^{26}$. Muestra, en suma, su preocupación por el potencial negativo sobre los intereses británicos en España y resulta muy revelador que haga estas referencias en un texto dedicado a la caída de Oropesa y al contratiempo que supone respecto a la sucesión española. En su contestación ${ }^{27}$, Vernon transmitía a Stanhope las garantías ofrecidas por el gobernador de Jamaica acerca que no habían tenido nada que ver con el asentamiento escocés, pero que, a pesar de ello, los españoles habían capturado algunos barcos ingleses, llevándolos a Cartagena de Indias. Inmediatamente Stanhope habría de presentar un memorial a Antonio de Ubilla con una explicación oficial inglesa. Según la misma, la iniciativa escocesa no solamente no había contado con su aquiescencia, sino también con su rechazo expreso en el Parlamento, que se habían dado instrucciones a las colonias inglesas de no colaborar con los escoceses, pero que reconocía sus dificultades para detener la aventura, debido a que «la materia es un poco delicada pues el Reyno de Escocia es del todo independiente de la Corona de Inglaterra de la misma manera que Aragon de la de Castilla»28. La respuesta oficial española no se hace esperar y el 21 de mayo Ubilla le hace entrega de la contestación española en la que se emplaza al rey de Inglaterra a detener el proyecto ${ }^{29}$.

Ya en el verano, se empieza a notar la repercusión de este asunto en los periódicos ingleses. Estableciendo claramente los riesgos que se cernían en caso de un éxito escocés, señaladamente el que los colonos reforzados en el Darién impedían una partida segura de los galeones y que estaba prevista una expedición contra ellos para antes de fin de ese año ${ }^{30}$. Efectivamente, el asentamiento se encontraba en una estratégica posición entre Portobelo y Cartagena de Indias, lo que amenazaba directamente la seguridad de las flotas y del comercio español. Aunque el primer reproche jurídico que se realiza desde España a la iniciativa es remitiéndose a la inter caetera y a la soberanía española sobre el territorio, hay otro extremo que resulta trascendental: la presencia de ministros calvinistas entre los expedicionarios y lo que suponía el primer templo hereje en el territorio continental de la América española ${ }^{31}$.

Es posible hacer un seguimiento de la aventura escocesa mediante la lectura de la prensa de Londres, que informaba sobre la respuesta española, los intereses amenazados o sus aspectos económicos. Así, la Corona solicitó ayuda a los comerciantes de Cádiz y Sevilla ${ }^{32}$, quienes se comprometieron a participar, garanti-

26 TNP SP 94/73 folio 158. Memorial al secretario Vernon de abril 19/IV/1699.

27 TNP SP 94/73 folios 163-165. Carta del secretario Vernon al enviado Stanhope fechada (O.S.) en 16 de mayo de 1699.

28 TNA SP 94/73 folios 169-170.

29 TNA SP 94/73 folios 171-172.

30 Flying Post or The Post Master, 9/IX/1699, nº 677.

31 Además de los dos señalados Cristopher Storrs añade como motivo que impulsaría una actuación española ante este suceso: el prestigio. Muy importante sobre todo para una gran potencia, opina él, consciente de su decadencia. Véase STORRS (Londres, 1999): 8.

32 Flying Post or The Post Master, 19/VIII/1699, nº66; Post Boy, 19/VIII/1699, nº 682. 
zando 500.000 pesos para la expedición contra el Darién ${ }^{33}$. También la Iglesia se mostraba muy inquieta por la presencia de misioneros calvinistas escoceses, preocupación que alcanzaba a la Santa Sede. Esto encuentra confirmación en la correspondencia diplomática del embajador Stanhope, quien hace saber a Londres que se ha recibido un despacho de Roma alertando sobre los peligros que a la religión provoca el establecimiento de los escoceses en Indias ${ }^{34}$. Las crónicas daban cuenta de la concesión de una bula papal que concedía tres millones de pesos para contribuir a una expedición que expulsara a los colonos ${ }^{35}$. Las cantidades habrían de ser libradas por los estados eclesiásticos del Perú y de Nueva España.

En julio, Stanhope vuelve a escribir a Vernon, advirtiendo de que los españoles estaban haciendo preparativos de guerra, comprando barcos a franceses $y$ genoveses para enviarlos contra los escoceses ${ }^{36}$. Expresaba que había sido imposible persuadirles de que no hubieran recibido refuerzos de hombres, provisiones y munición desde Jamaica, Barbados y Nueva Inglaterra. Efectivamente, ya a partir de estos momentos, la aventura de los escoceses del Darién y los preparativos de una expedición contra ellos para desalojarlos son una notica habitual en los periódicos y lo habrían de ser durante todo el tiempo que duró el proceso sucesorio español ${ }^{37}$.

A pesar de las dilaciones que fue sufriendo la reacción contra los escoceses desde la metrópoli, la reacción de las autoridades indianas fue rápida, organizándose expediciones desde Panamá y Cartagena de Indias que, aunque no consiguieron expulsar a los colonos, sí que les sometieron a presión, les situaron en la necesidad de solicitar auxilio a las colonias británicas de ultramar, y les enfrentaron a la posibilidad de un eventual fracaso ${ }^{38}$. Además, procuraron las primeras noticias sobre combates entre escoceses y españoles en el Darién agrupando distintas variables del problema ${ }^{39}$. Del tratamiento de la información se trasluce un

${ }^{33}$ Post Man and the Historical Account, 19/VIII/1699, nº 649.

34 TNP SP 9473, fol. 177. Carta de Stanhope al secretario Vernon.

${ }^{35}$ Con idéntica fecha se recoge en el Post Man and the Historical Account, 1/VIII/1699, n 638; y en el Post Boy, 1/VIII/1699, $n^{\circ}$ 674. Las noticias difieren en cuanto a la moneda, en el Post Boy se habla de "Coronas" y en el Post Man de piezas de a ocho, que debe ser la correcta toda vez que se trata de cantidades de américa y por ello hemos reflejado "pesos» en el texto. En cuanto a la cantidad, la cantidad concedida por la bula fue de sólo un millón.

${ }^{36}$ TNP SP 94/73, folio 176

37 Post Man and the Historical Account, 29/VII/1699, n 637; Flying Post or The Post Master, 12/ VIII/1699, nº65, y Flying Post or The Post Master, 15/VII/1699, nº 653.

${ }^{38}$ Como escribe Christopher Storrs además de la reacción desde la península, el poder español tenía la posibilidad de reaccionar in situ. La armada de Barlovento y las posiciones españolas en América garantizaban dicha posibilidad y además en lo que constituye la tesis central de su artículo, y quizá de su obra historiográfica referida al sistema español, a pesar de la evidente decadencia del poder español, éste seguía siendo uno de los grandes poderes mundiales del momento y los recursos que podía movilizar en su defensa, más que considerables. STORRS (Londres, 1999): 10/13.Su pensamiento sobre sobre el mantenimiento de la potencia española en STORRS, 2006.

${ }^{39}$ London Post with Intelligence Foreign and Domestick, 9/VIII/1699, $\mathrm{n}^{\circ}$ 29. «We had letters come by the last Post, from Amsterdam wich tell us, that a Dutch Ship, which left Jamaica the 20th of May, 
apoyo a los colonos. Denota una clara simpatía por ellos, resaltando su valentía y el desafío que lanzan al poder imperial español, «to give the Spaniards a warm Reception " ${ }^{40}$. Las noticias también hacen explícito el apoyo que los colonos obtuvieron de las colonias inglesas en su aventura y, por tanto, justifica los temores y recelos españoles ante la posición inglesa sobre el asunto ${ }^{41}$. El embajador marqués de Canales había informado a Madrid del proyecto desde sus primeros pasos, ya en enero de $1696^{42}$. No cabe duda de que tenía acceso a los periódicos y que, transmitida dicha información, resulta lógico que, como arriba veíamos, a Stanhope le resultara muy difícil persuadir a los españoles de que las colonias inglesas no estuvieran prestando su concurso a los escoceses. Por último, como es natural y ya hemos visto reflejado en la correspondencia entre Stanhope y Vernon, no tardaron en llegar noticias sobre la escalada de acontecimientos que implicaban a embarcaciones españolas e inglesas, con una cierta contención, pero que implicaban un riesgo grave de deterioro de las relaciones entre ambas potencias $^{43}$.

was arrived there and reports, that before the came away abundance of Scots arrived daily there from Darien, and amog them Several of the chiefest of them, which said that they have left that place for want of Provisions, Money, and other necessaries; in so much that they could not subsist there; and that was feared, that soon want of Succour, they would be all obligated to quit their new Settlement, and to abandond their Forty. But These reports meet with no credit here, and the less because the Happy Return which left Jamaica towards the latter end of June, and arrived in the Downs on Wednesday last, gives us a different account, and tell us, that they want for nothing, having lately received considerable supplies from that and the other neighboring Islands; and that notwithstanding all endeavors, have been used in those parts to prevent the Inhabitants to go thither, yet many of them go daily to joyn the Scots, and are very kindly and well received. She adds that the Scots are viewing the Country round them in small Parties, have had several Skirmishes with the Spaniards, and always obtained the Victory, which uninterrupted Successes, together with the Strength of their Fortifications and the great numbers of brave Scout Men that have lately joyned them, have rendered them very terrible to the Spaniards, and in a manner, struck them with a pannique fear. However, she adds, that the Spaniards are resolved to try their last efforts, and for that end, are drawing together all the Force they can from Peru, Mexico, Carthagena, and their other Territories; all which the Scots, in a manner laugh at, and have sent home some Prisoners to advise them to Fortity the afore mentioned Places, and Guard them well to prevent a surprize; in the meantime, they were preparing all things at home, to give the Spaniards a warm Reception, if they should come down upon the mentioned Force».

40 lbíd.

${ }_{41}$ Sobre el apoyo de las colonias y la respuesta inglesa, BINGHAM (Bloomington, 1905): 812/815.

42 STORRS (Londres, 1999): 21.

${ }^{43}$ London Post with Intelligence Foreign and Domestick, 28/VIII/1699, $\mathrm{n}^{\circ} 37$. «Our merchants have Advice, that a Spanish ship Cruizing off the Isle of May, met and took and small english Vessel, which she supposed belonged to the Scots, and detained her three days upon mature Consideration, what the Consequence of Such an Action might be, if she should really prove an English ship, they dimissed her By this Action we may plainly find, that the Spaniards keep a very watchful eye upon the motion of the Scots, and that consequently they will use their utmost indeavours to intercept the last Convoy that sailed from Scotland to Darien. However it be, we are still assured by all Ships that come from the Plantations, that the Scots are so well Fortified there, that it will be hard for all the force of Spain in the West-Indies to dislodge them.In the meantime we are told, that some secret Orders have been lately sent hence to the English Plantations, in relation to the said Settlement; as also that 5 men of war are ordered to sail forthwith for the West-Indies, to reinforce the English Squadron under Admiral Bemborn in those parts; and they are to carry them good store of Provisions, which they are to take in Ireland, the said Admiral, as 'tis reported, being to carry there all next winter's. 
Tras esas primeras escaramuzas, que se correspondían con la expedición de Canillas, se interpreta en la prensa de Londres que ha habido un cambio de estrategia de los españoles, quienes parecen dispuestos a bloquear el Darién por tierra y mar, sin realizar un asalto ${ }^{44}$. Una gran atención se centra entonces en los preparativos militares que se realizaban en Cádiz, que habrían de acompañar al nuevo gobernador de Cartagena de Indias, Juan de la Pimienta, en las órdenes para disponer barcos y soldados, o en la intención de que salga el contingente antes de fin de año ${ }^{45}$. Stanhope también se hacía eco de estos planes:

«They are sending with all expedition three small vessels with arms ammunition \&c to Carthagena to be employed against the six Scotch heretic ministers at Darien who stick more in their stomachs here than all the other 1200 fighting laymen put together» ${ }^{46}$.

La prensa destacaba la irritación que este asunto causa en Madrid, lo que llega a ocasionar que no se de audiencia al embajador inglés ${ }^{47}$. La agitación incluso se incrementaba con las informaciones sobre un proyecto francés de realizar otro asentamiento en América ${ }^{48}$. Sin embargo, pronto se recibirían noticias en Londres del primer abandono escocés ${ }^{49}$. Semanas más tarde, los corresponsales de Madrid también informaban de que se habían recibido en España desde Cádiz y Flandes y Stanhope mismo se hace eco del alivio que produce en Madrid esta noticia ${ }^{50}$. En Loo, Guillermo III también se felicita, aunque con ciertos matices ${ }^{51}$. Las buenas noticias hacen que desde España se retomen los propósitos de enviar

44 Post Boy, 29/VIII/1699, nº 686.

45 Passim: Flying Post or The Post Master, 5/IX/1699, $\mathrm{n}^{\circ}$ 675; London Post with Intelligence Foreign and Domestick, 15/IX/1699, $\mathrm{n}^{\circ}$ 45; Flying Post or The Post Master, 9/IX/1699, $\mathrm{n}^{\circ}$ 677; Post Boy, 9/IX/1699, $\mathrm{n}^{\circ}$ 691; London Post with Intelligence Foreign and Domestick, 28/IX/1699, $\mathrm{n}^{\circ}$ 50; Flying Post or The Post Master, 28/IX/1699, $\mathrm{n}^{\circ}$ 685; Post Boy, 28/IX/1699, $\mathrm{n}^{\circ}$ 699; Post Man and the Historical Account, 5/X/1699, $\mathrm{n}^{\circ}$ 666; London Post with Intelligence Foreign and Domestick, 11/X/1699, $\mathrm{n}^{\circ}$ 56; Flying Post or The Post Master, 19/X/1699, $\mathrm{n}^{\circ} 694$ y Post Man and the Historical Account, 19/X/1699, $\mathrm{n}^{\circ} 666$.

46 Lord MAHON, 1744, 187, carta al earl de Jersey, 26/VIII/1699.

47 Flying Post or The Post Master, 16/IX/1699, no 680; Post Boy, 16/IX/1699, nº 694.

48 Informaciones sobre la partida de una flota al rio Mississippi a establecer una colonia y la irritación que causa en Madrid, en Post Man and the Historical Account, 19/IX/1699, n 659. Sobre este tema Stanhope escribe al secretario Blathwayte. En 27/VIII/1699, "As to what you say of the French new settlement on the river Mississippi, it ought to alarm them here as much as our Scots, but as yet having it only extrajudicially by common fame they take no notice of it being not consistent with their gravity to seem to believe anything till they have the advice from their own Governors in those parts, as possibly they may of this a twelvemonth hence", Lord Mahon, Spain..., pág. 187. También, sobre este tema, BERNARDO ARES (Madrid, 2006): 180.

49 Post Man and the Historical Account, 3/X/1699, $\mathrm{n}^{\circ} 665$, da cuenta del abandono; Flying Post or The Post Master, 17/X/1699, n 693, da detalle del mismo.

50 Flying Post or The Post Master, 4/XI/1699, n 701; Post Boy, 4/XI/1699, n 715; «TO MR STANYAN SECRETARY OF EMBASSY PARIS, Madrid, October 22, 1699. This Court is extremely pleased with the advice of the Scots removal from Darien which was a thorn they would never have been able to have pulled out without assistance from yours, and I assure you it was very lustily promised and would certainly have been accepted if the news had staid a little longer». Lord MAHON, 1744, 192.

51 «Though I am very glad at being now relieved from embarrassment about the affair of Darien, I pity with all my heart the poor Scotch, who have lost every thing, and were by no means the promoters 
pronto los galeones a tierra firme ${ }^{52}$. Por último, Harcourt transmite estas noticias a su soberano, quien había vuelto a realizar un ofrecimiento a través de la Santa Sede para ofrecer la asistencia de Francia en el desalojo de los escoceses ${ }^{53}$.

\section{RUPTURA DIPLOMÁTICA}

Durante el otoño de 1699 se produjo una gran confrontación de España con las potencias navales, coincidiendo con el asunto del Darién. La muerte del príncipe José Fernando de Baviera, supuso también la del tratado de reparto de 1698 . Ante esto, las potencias firmantes iniciaron conversaciones destinadas a lograr un nuevo acuerdo sobre la sucesión de Carlos II. Las negociaciones se habían iniciado inmediatamente después de la muerte del príncipe entre Portland y Tallard en Londres, y se había llegado a un preacuerdo en mayo de 1699, plasmado en un proyecto de tratado de 11 de junio de $1699^{54}$. Entonces se produce la interferencia de la propia España, que había tenido conocimiento ya de las conversaciones. Stanhope escribía a Manchester, nuevo embajador en París, el 27 de agosto, adjuntándole una nota recibida del secretario Ubilla ${ }^{55}$. Por su parte, Portland informaba de que el descubrimiento habría sido hecho por Quirós y Guillermo III decide consensuar su respuesta a España con Heinsius, pero manifestando que «/t is difficult to reply on so important a matter, when it is not admissible to speak the simple truth» ${ }^{56}$. Esto, como resulta obvio, incrementaba la dificultad de la gestión

of this enterprise. I fear, too, that this will cause many quarrels in Scotland, from which I too may have to suffer», Guillermo III al earl de Portland, Loo, 29/IX/1699, en GRIMBLOT, 1848, 354.

52 Flying Post or The Post Master, 23/XI/1699, $\mathrm{n}^{\circ} 709$.

53 Harcourt a Luis XIV, Madrid, 22/X/1699, «Pocos días atrás llegó correo de Roma (...) traía también un paquete para el Nuncio, el cual apenas lo recibió pidió audiencia, contestándosele que dijese por escrito lo que se le ofrecía, a menos que tuviese que hablar personalmente con el Rey. Envió entonces una nota explicando que S. S. había escuchado al Príncipe de Monaco que el Rey Cristianísimo está dispuesto a juntar sus fuerzas con las españolas para expulsar a los escoceses de Darién, siempre que S. M. Católica le indicase que lo deseaba. Esa nota se envió al Consejo de Estado, y se estaba ya deliberando sobre ella con mucha inclinación a aceptar el ofrecimiento, cuando llegó carta del Marqués de Canales desde Inglaterra notificando que los escoceses habian abandonado Darién luego de arrasar las fortificaciones, a causa de la inclemencia del clima y de la falta de víveres; con lo cual el Consejo acordó suspender todo acuerdo de consulta hasta que se recibieran del Escorial las órdenes de S. M'. cuando haya sido confirmada la noticia de Canales. (...) Ha indicado el Nuncio que no era necesario divulgar el ofrecimiento. Se sabe, sin embargo, lo ocurrido porque en el Consejo de Estado español no se guarda ningún secreto. Por eso podrá darle cuenta de lo que se acuerde contestar en cuanto se formule la consulta. (...) La noticia de que los escoceses evacuaron Darien se ha confirmado, según dicen, por un navio que acaba de llegar a Bilbao. No se ha contestado al Nuncio, pero se ha elevado consulta al Escorial, opinando unánimemente que procede dar las gracias a S. M. Cristianísima; en primer término, porque la oferta lo merece y en segundo, porque puede ser necesaria otra vez, conviniendo mucho en todo caso que vean en Europa hasta qué punto se extrema la reconciliación sellada en Rijwick». Tomado de DE BAVIERA y MAURA GAMAZO, 2004, 1111/1113.

54 Se puede seguir el proceso y su repertorio documental en Paul GRIMBLOT 1848, y, naturalmente, en LEGRELLE1890. Sobre las negociaciones del tratado, véase TROOST, 2005, 253/258. THOMSON (Londres, 1954): 111/134. BÉLY, 2007, 631/652.

55 GRIMBLOT, 1848, 344. Carta de Stanhope a Manchester, Madrid, 27/VIII/1699.

56 Ibíd, 345/346. Carta de Guillermo III a Heinsius, Loo, 13/IX/1699. 
de la cuestión española, al tener que elaborar una explicación coherente que dar a Madrid. Liberándose de decir la sencilla verdad, el rey de Inglaterra podía esperar acordarla con las Provincias Unidas, pero no el olvidar que Francia podría desdecirle:

«I confess I find myself embarrassed what answer to give, touching the memorandum Count Tallard gave the Earl of Portland, which has been sent to the Marquis d'Harcourt. It is in substance what Quiros has said to you and the Earl of Portland. My embarrassment is, that I cannot hinder France from making the negotiation public, though I do not approve the answer France intends to give Spain; and, should I approve it, then the treaty must go forward immediately, or very soon at least» 57 .

El memorándum al que se refiere son las instrucciones dadas a Harcourt en julio para reconocer en Madrid la existencia de las negociaciones, aunque dichas órdenes fueron anuladas en una carta de 16 de agosto, por las que Luis XIV difería la comunicación hasta tener la aceptación de Leopoldo I, o en su defecto, como ocurrió, hasta haber firmado el acuerdo separado ${ }^{58}$. Por tanto contesta a España mediante una nota calculadamente ambigua que Portland comunica, sin entregársela, a Quirós y que, difícilmente podría considerarse como satisfactoria ${ }^{59}$.

La prensa de Londres tendrá acceso a la información sobre las negociaciones y el 3 de octubre se publica que continúan las conversaciones entre Portland y los embajadores de Francia relativas a la sucesión española, fundamentadas en salvar de peligros a Europa. Se dice que el embajador Quirós está esperando la llegada allí de Guillermo III para presentar una protesta formal ellas ${ }^{60}$. El 6 de octubre describen la irritación de Quirós, y sus gruesas palabras: «one would think by his discourse that he fancies himself to be ambassador of Charles the 5th or Philip the Second ${ }^{61}$. Esta escalada de tensión sobrepasa un punto crítico cuando el London Post informa de que el embajador español en Londres, el marqués de Canales, ha sido enviado en un barco a Francia, para regresar a España, y también se especula con que el enviado inglés en Madrid, Stanhope, va a ser llamado también, aunque dice que las razones de estos movimientos permanecen en el misterio ${ }^{62}$. A estas alturas, y en pleno desarrollo de la aventura escocesa, el tono

57 Ibíd, / 346. Carta de Guillermo III a Heinsius, Loo, 19/IX/1699.

58 lbíd, 511/513.

59 «El conde Portland me lleyó una carta de mano propia del Rey, en que expresa S. M. B. que, haviendose aplicado casi toda su vida à mantener los intereses de $V$. M. en guerra y en paz, conservando siempre la buena union y amistad con V. M., como era notorio lo havia praticado hasta aora, continuaria en este mismo sentir, sin que huviese obrado ni pensase hazer cosa que le pareciere que podria ser contra los reaies intereses de V. M. y de la monarchía, de que me encargava asegurare yo à V. M. «, Quirós à Carlos II, 29/IX/1700, en LEGRELLE, 1890, 140.

${ }^{60}$ London Post with Intelligence Foreign and Domestick, 27/IX/1699, $\mathrm{n}^{\circ} 50$. El día siguiente, el resto de la prensa de Londres salió con idéntica noticia: Flying Post or The Post Master, 28/IX/1699, $n^{\circ} 685$; Post Boy, 28/IX/1699, n 699 y Post Man and the Historical Account, 28/IX/1699, nº 663.

${ }_{61}$ Post Man and the Historical Account, 30/IX/1699, n 664.

62 London Post with Intelligence Foreign and Domestick, 2/X/1669, $\mathrm{n}^{\circ} 52$. 
de la prensa de Londres ya es claramente antiespañol, como se desprende de estos comentarios a un panfleto relativo a los temas en disputa diplomática:

«Sure one needs not be a Conjurer, to guess that this was written beyond the Pyrinees Hills, and that the Penman was drunk of the waters of the famous Mansanares, or breath'd the Air of La Mancha; for anybody else have sooner beaten out his own Brains, than have discovered the secret this Don... has imparted to the world; I mean that the King of Spain entred into the late War in favour of the King of England, (...) it was in the days of Don Quixote» ${ }^{63}$.

Noticias desde Bruselas, fechadas en 16 de octubre, despejaban el misterio arriba indicado ${ }^{64}$. Las conversaciones y el proyecto de partición habrían provocado por parte del embajador Canales la presentación de un memorial ante los Lords of Justice $^{65}$. Éste, por su tono y determinadas expresiones — que califica de «odd an uncivil» la fuente- contenidas en él y, sobre todo, por el órgano elegido, que podría crear un problema constitucional, irritaron a Guillermo III quien ordena su inmediata expulsión del reino. En cadena, se produjo la retirada de los enviados en Flandes de Inglaterra, Mr. Hill y de Provincias Unidas, M. Dickvels, en una rápida escalada de acontecimientos. Un número posterior del Post Man informará de un memorial parecido presentado ante los Estados Generales ${ }^{66}$. Se llega en este momento a una total falta de comunicación entre ambos reinos, en un ambiente de elevada tensión ${ }^{67}$.

Hay una primera referencia a la protesta de Canales en la correspondencia de Guillermo III de 26 de septiembre, pero sólo es una referencia genérica a la impertinencia del marqués ${ }^{68}$. Pero es el día 29 cuando escribe a Portland analizando detalladamente las consecuencias de la protesta de Canales ${ }^{69}$. Esta carta demuestra claramente el contratiempo que supone para él, forzándole a depender de Francia en su contestación a España y originando unas premuras en la ratificación de un reparto que hasta ese momento estaba deliberadamente tratando de posponer.

En la protesta presentada por Stanhope en Madrid por este asunto, se achacaba al marqués haberse enfrentado al rey ingles «By appealing to the Parliament and people of England against his Majesty», con palabras contumaces, insidiosas y equívocas ${ }^{70}$. Inglaterra, por su parte se mantiene firme en su postura de achacar

63 Post Man and the Historical Account, 5/X/1699, n ${ }^{\circ} 666$.

64 Post Man and the Historical Account, 10/X/1699, n662.

65 El texto integro del memorial de Quirós, en Paul GRIMBLOT (ed.): Letters..., págs. 354-346.

66 Post Man and the Historical Account, 14/X/1669, n664.

67 Flying Post or The Post Master, 17/X/1669, nº 693.

68 GRIMBLOT, 1848, 354. Carta de Guillermo III a Heinsius, Dieren, 26/IX/1699:»I hope you may still be able to delay giving a positive answer to the French ambassadors, though the impertinent memorial of the Spanish ambassador at London should make me rather hasten the negotiation».

69 GRIMBLOT, 1848, 354/357. Carta de Guillermo III a Portland, Loo, 26/IX/1699.

70 Memorial presentado por Stanhope a Antonio de Ubilla, Madrid, 3/XI/1699, en Lord MAHON, 1744, 192/194. Motiva su protesta en la actitud de Canales «appealing to the Parliament and people of England against his Majesty». 
la culpa de este asunto a la actuación del embajador español, exigiendo una satisfacción por ella y obviando cualquier reconocimiento sobre las «pretendidas» conversaciones sobre la partición ${ }^{71}$.

El 6 de noviembre en la Haya se sigue esperando la respuesta de Madrid, para saber cuál será la contestación relativa a la satisfacción solicitada por Inglaterra, aunque la creencia es que el asunto se va a prolongar, y que el embajador Quirós se hará cargo de todos los asuntos de España ${ }^{72}$. El Consejo de Estado de los Países Bajos Españoles habría escrito a Madrid rogando se procurara una satisfacción a Guillermo III respecto al affaire del embajador Canales ${ }^{73}$. De momento, las únicas noticias de Madrid respecto a este asunto son de 22 de octubre e indican que Carlos II habría recibido un expreso de Canales y se le habría ordenado el regreso inmediato a España ${ }^{74}$. Por otra parte, el marqués de Canales fue recibido con grandes honores por el gobernador de Calais en su tránsito a Bruselas, lo que habría ocasionado «many reflections here» ${ }^{75}$. El propio Guillermo III reflexionaba sobre este asunto:

«I am not well pleased at in this conjuncture, but I do not think I could have avoided it; it is, however, impossible to put up with such insolence. I doubt not that France will be very glad of it, and that she will see that I shall be now more eager speedily to conclude the treaty ${ }^{76}$.

Poco después, se conoce la respuesta española a Inglaterra: un correo llegado a La Haya desde Bruselas, informaba de que el rey de España había prohibido el embarque de mercancías españolas en barcos ingleses, y ordenado que Mr. Stanhope, el enviado inglés, saliera inmediatamente de sus dominios ${ }^{77}$. Es decir, la interrupción completa de las relaciones diplomáticas entre ambas potencias. Aunque el Post Boy también presentaba en su información que la salida del diplomático inglés era a consecuencia de instrucciones de Londres, quien le habría llamado a consultas, sin embargo el propio Stanhope desmiente este extremo, demostrando la proporcionalidad de la contestación española ${ }^{78}$.

\footnotetext{
71 Post Boy, 24/X/1669, nº 710 .

72 Post Boy, 31/X/1699, $n^{\circ} 713$. No podemos dejar de referir aquí, la posterior carrera del embajador Quirós en el bando del Archiduque, véase OZANAM, 1998, págs. 185/186.

73 Post Boy, 4/XI/1699, no 715, y Flying Post or The Post Master, 4/XI/1699, no 701.

74 Post Boy, 4/XI/1699, no 715.

75 Flying Post or The Post Master, 9/XI/1699, no 703.

76 Guillermo III a Portland, Loo, 29/IX/1699, en GRIMBLOT, 1848, 349.

77 Post Boy, 14/XI/1699, n 719; Flying Post or The Post Master, 23/XI/1699, no 709, y Post Boy, 23/ $\mathrm{XI} / 1699, \mathrm{n}^{\circ} 723$.

78 «The next day after my last I had certain notice from several hands the King has taken his resolution of ordering me to begone; whereupon at midnight I dispatched to the Escurial my agent with the paper, of which the enclosed is a copy. The secretary of the Despacho Universal, Don Antonio de Ubilla, would no receive it, but was willing to hear the contents by word of mouth, and that was as much as I desired. Two days after, the Conductor, or Master of the Ceremonies, came to order me, in the King his Master's name, to be gone out of the Spanish dominions in eighteen days, and not to stir out of my house till I should begin my journey. I have every day since solicited my passports, being ready to begone whenever they give me; and am told the reason of the delay is to know by next post whether any
} 
Simultáneamente, se empieza a abrir paso la preocupación inglesa por el impacto de la ruptura diplomática en las relaciones comerciales, como por ejemplo entre los mercaderes ingleses de Málaga ${ }^{79}$. Una información de Cádiz, de 28 de noviembre, demuestra las consecuencias de este episodio. El temor a una ruptura de las hostilidades con Inglaterra habría provocado una intensa actividad de recobro de débitos, un rápido deterioro del crédito y una depresión o interrupción de la actividad comercial ${ }^{80}$.

En noviembre Stanhope había salido ya de España a través de la frontera con Francia ${ }^{81}$. Esto se confirmaba, días después, en el Post Man que, sin embargo, trataba de presentar la expulsión como que el diplomático inglés obedecía órdenes previas de regresar a Inglaterra y de hacer una fuerte protesta ante el rey de España ${ }^{82}$. También se publicaba que el Consejo de Estado habría disculpado la actuación de Canales y ordenado la preparación en Cádiz de algunos navíos de línea y de acondicionar las defensas, se entiende que en previsión de un ataque inglés, y se empieza a hablar de una mediación del Emperador ${ }^{83}$.

En suma, el año de 1699 terminaba con una grave falta de comunicación diplomática entre Londres y Madrid que se habría de prolongar durante el año siguiente, cuando se iban a recibir en Europa las noticias del segundo asentamiento escocés, la ratificación del Tratado de partición de Londres y que se habría de prolongar mientras se verificaba el cambio dinástico en España.

\section{LA RESPUESTA DE MADRID}

Durante unos meses se habían dejado de producir novedades sobre los escoceses aunque una noticia de primeros de diciembre permite deducir que en Madrid se habría tenido alguna referencia sobre la partida de la segunda expedición desde el Clyde, que provocó que se despachasen alertas a América ${ }^{84}$. Es ya a partir de febrero cuando se empiezan a recibir las confirmaciones del nuevo asentamiento escocés ${ }^{85}$, lo que, naturalmente, provocaba un nuevo ofrecimiento

passports, and in what form, were given to the Marques de Canales, in London, that they may exactly imitate the same with me", Stanhope al earl of Manchester, embajador en Paris. Madrid, 12/XI/1699, en Lord MAHON, 1744, 195/196.

79 "Darmouth, Nov. 26. The Revenge Gally is arrived here from Malaga, and reports That the English There were in great Fear, left their Effects and Ships should be seized, upon a Rumor that have been spread there by some ill people, as if Spain Proclaim War against England, but judicius Men gave no Credit to this Report, well Knowing that they are not in condition to do it", en Post Boy, 28/XI/1669, $n^{\circ} 725$. Más referencias en Flying Post or The Post Master, 25/XI/1699, n 710.

80 Post Man and the Historical Account, 16/XII/1699, no 690

${ }^{81}$ Post Boy, 28/XI/1669, no 725.

${ }^{82}$ Post Man and the Historical Account, 28/XI/1699, nº 682.

${ }^{83}$ Ibíd.

${ }^{84}$ Post Man and the Historical Account, 16/XII/1699, nº 690.

${ }^{85}$ Post Man and the Historical Account, 22/II/1700, n 716; Post Boy, 27/ll/1700, n 763; Post Boy, 26/III/1700, nº 774 . 
de Francia ${ }^{86}$. Y en abril, se tenían «avisos de haver desembarcado los escoceses 1100 hombres en el Playón del Darién, sin la chusma de mujeres y niños, y que se fortificaban de nuevo ${ }^{87}$. Con estas noticias, como es natural, vuelven a ponerse en marcha los preparativos en América y en Cádiz. De Cartagena de Indias los periódicos informaban de que se estaba preparando una gran expedición con ocho mil hombres, cifra que, semanas más tarde, se rebajan a dos mil, acompañados de cinco navíos, cuando se da la noticia de su salida ${ }^{88}$. Esta expedición es la de Juan de la Pimienta que conseguiría la definitiva capitulación escocesa.

En cuanto a Madrid, la preocupación por este tema y, posiblemente, la coincidencia con el conocimiento del tratado de partición, ocasionan que se haga un gran esfuerzo en el preparativo de una expedición de desalojo en Cádiz ${ }^{89}$. Para tal fin se decidió organizar un fuerte contingente de tres mil soldados acompañados de una considerable flota. Para cubrirlos, se realizan levas en Castilla y en Andalucía, se retiran dos tercios de veteranos de Ceuta y se asignan varias compañías de valones, es decir, tropas de primera calidad puestas bajo el mando de un comandante experimentado, veterano de Flandes, Pedro Fernández de Navarrete. Desde luego se trataba de una demostración muy clara de la seriedad con que se tomaba este episodio en España.

Sobre este asunto resulta de gran interés la consulta del Consejo de Estado realizada para tratar sobre las órdenes de Navarrete y decidir sobre el tratamiento que se habría que dar a los escoceses que fueran capturados ${ }^{90}$. La fuerza reunida en Cádiz estaba compuesta por "diez navíos y dos barcos luengos» y sus instrucciones consistían, básicamente, en atacar a los escoceses y desalojar la colonia. Con tal propósito se libraron órdenes para disponer de 200.000 pesos en Panamá de la contribución del subsidio eclesiástico y para que desde Quito, Nueva Granada y Méjico se remitieran sendos envíos de 50.000 pesos cada uno, con cargo al mismo expediente. Además se ordenaba al Presidente de Panama que "asista con todo lo necesario al sustento desta armada».

Respecto a que hacer con los escoceses, todos los miembros del Consejo expresaron opiniones en el sentido de considerar a los aventureros como piratas

${ }^{86}$ London Post with Intelligence Foreign and Domestick, 8/III/1700, $\mathrm{n}^{\circ} 119$

87 AHN Estado 702 20, acuerdo del Consejo de Estado, 22/V/1700.

88 Post Man and the Historical Account, 28/III/1700, $\mathrm{n}^{\circ} 731$; London Post with Intelligence Foreign and Domestick, 31/V/1700, n 155.

89 Se pueden seguir los preparativos en los siguientes periódicos: Post Man and the Historical Account, 22/II/1700, n 716; London Post with Intelligence Foreign and Domestick, 8/III/1700, n' 119; Post Man and the Historical Account, 6/IV/1700, $n^{\circ} 735$; Post Boy, 11/IV/1700, $\mathrm{n}^{\circ} 782$; Post Man and the Historical Account, 18/IV/1700, $\mathrm{n}^{\circ}$ 740; London Post with Intelligence Foreign and Domestick, 29/IV/1700, $\mathrm{n}^{\circ}$ 141; Post Man and the Historical Account, 9/V/1700, $\mathrm{n}^{\circ} 749$, y en Flying Post or The Post Master, 16/V/1700, nº 784. Sobre esta expedición, STORRS (Londres, 1999): 23-27.

90 AHN Estado 702 16, acuerdo del Consejo de Estado, 6/VI/1700, realizado «con vista de la consulta de la Junta de Guerra de Indias en que incluye las instrucciones que se le han de dar al almirante gral. D. Pedro Fdez. Navarrete para su partida a desalojar a escoceses en el Darién". 
y castigarles como tales. Como señala Villafranca, «haviendo el Rey de Inglaterra dado a entender o dicho que estos no han ydo con orden ni permisión suya con q el mismo rey libra del reparo q se podría tener con ellos solo por apresarles, pues con esta declaración suya no pueden tener otro nombre que el que va referido de Piratas» ${ }^{91}$. Y también es muy significativo el del marqués del Fresno:

«se puede estimar este por un insulto que merecía en lo universal estando en postura competente el poder VM ${ }^{g d}$ con justizia hazer la guerra al Rey de Inglaterra, pero que las cosas se miden conforme a la disposizion y poder en los Reyes, que haze VMgd un dispendio y un gesto tan crezido que todas sus fuerzas y caudal es menester emplearlas en su devida satisfación y consuelo a los vasallos de la América que vean que tienen amo con potencia que los puede protexer y defender de tales enemigos» 92 .

La noticia de la definitiva capitulación escocesa fue publicada en Londres el 22 de junio de 1700, citando informaciones de Nueva York, fechadas en 16 de mayo, con el testimonio de algunos supervivientes ${ }^{93}$. Sin embargo la información no llegó a Madrid hasta pasadas algunas semanas y las órdenes de detener la salida de Navarrete no llegaron a tiempo ${ }^{94}$. La flota había partido de Cádiz el 19 de junio y se preveía que los Galeones lo hicieran en agosto ${ }^{95}$. La confirmación oficial del definitivo desalojo escocés llegaría primero en agosto a través de los representantes en París y Londres, el embajador Castelldosrius y el cónsul Bernardino Navarro, y posteriormente de Indias, en septiembre, cuando se decide hacer volver la expedición de Navarrete, que no estaría de vuelta en Cádiz hasta enero del año siguiente ${ }^{96}$.

Antes de la marcha de la expedición de Navarrete, el Consejo de Estado se reunía el 12 de junio de 1700, con carácter extraordinario y urgente ${ }^{97}$. Asistieron el cardenal Portocarrero, el duque de Medina Sidonia, los marqueses de Mancera, de Villafranca y del Fresno, y los condes de Frigiliana, de Santisteban y de Montijo. El conde de Fuensalida excusó su asistencia por una indisposición. El motivo de la convocatoria era una consulta urgente enviada por el secretario Antonio de Ubilla, a instancias del rey, sobre si convenía enviar la flota de Navarrete o si, por el

\footnotetext{
91 lbíd.

92 Ibíd.

93 Flying Post or The Post Master, 22/VI/1700, $\mathrm{n}^{\circ} 800$.

94 Post Boy, 18/VII/1700, $\mathrm{n}^{\circ}$ 824, y London Post with Intelligence Foreign and Domestick, 22/VII/1700, $\mathrm{n}^{\circ} 177$.

95 «Cádiz, June, 21. Two days ago, the King's squadron Crouded with Men, sailed for the West Indies, as well to Dislodge the Scots from Darien, as to Guard the coasts of the Indies; this makes us presume that the Galleons may be ready in August next». Post Boy, 13/VII/1700, nº 822.

96 AHN Estado 702 72, acuerdo del Consejo de Estado, 7/VIII/1700 y AHN Estado 702 82, acuerdo del Consejo de Estado, 3/IX/1700.

97 AHN Estado 702, acuerdo del Consejo de Estado de 12 de junio de 1700. Todas las referencias y citas de la mencionada reunión se corresponden con dicha signatura. En el mismo se describe la fuerza de Navarrete como «el Armamento hecho de ocho vaxeles y dos varcos luengos con la tripulación nezesaria y dos mil infantes de desembarco».
} 
contrario, "si convendrá que por la novedad que el Con tiene presente se reserve aquí esta esquadra» Como correspondía, tomó primero la palabra el presidente del Consejo de Estado, el cardenal Portocarrero, quien emitió su voto en estos términos:

«El Cardenal Portocarrero dice que aunque en donde ay poco y es menester asistir a mucho, puede hacer mucho al caso no dexar de valerse de todas las fuerzas que se pudiere, y considera que lo q se necesita en España, y que la causa de relixion se interesa tanto en defender esta cabeza quando en el disignio que se lleva de asegurar de erexes el darien, toda vía le hace gran peso no mudar esta facción y contramandar las fuerzas que estén ya para hacerse a vela a las Indias pues quando todo quedara no alcanza a nuestra defensa y el dexar de yr será de mucho embarazo porque peligraba tanto aquel importante comercio y principalmente el desaloxar los escozeses a que se añade las perdidas tan crezidas de considerables caudales que están empleados a este fin, porque pareze al Cardenal mande $\mathrm{V} \mathrm{M}^{\text {gd }}$ se execute lo resuelto».

A continuación, el marqués de Mancera se expresaba en conformidad con el voto del cardenal. Después de él, se produjo la única intervención discordante, la de Frigiliana, fundamentada en los riesgos que se derivarían de un fracaso de la expedición. Después de él, todos los participantes se mostraron conformes con enviar la expedición de Navarrete. El marqués de Villafranca proponiendo que, una vez enviada la escuadra, se pongan rápidamente en marcha los preparativos para mandar también los galeones. El marqués del Fresno expresaba un nuevo argumento: dado que la Santa Sede había otorgado una la bula, "podemos hacer la quenta de que la Iglesia costeará este Armamento". Por su parte, Santisteban se mostraba partidario de «mantener en la forma $q$ se pudiere algo de reputazion, le pareze $q$ se perdería mucha en detener este socorro q ya está para pasar a las Indias». El duque de Medina Sidonia y el conde de Montijo se mostraron partidarios, con la mayoría, de la salida inmediata de la fuerza. Por último, Frigiliana modificaba su voto, uniéndose a la mayoría y se consiguió la unanimidad del Consejo de Estado sobre la conveniencia de continuar adelante con la empresa.

\section{CONCLUSIONES. EL DARIÉN Y LA SUCESIÓN ESPAÑOLA}

Respecto a la designación de Felipe de Anjou como heredero del trono español existe una cuestión de gran interés que es saber cuándo, exactamente, se tomó la decisión. Formalmente, el testamento fue otorgado el dos de octubre pero, como es obvio, debía de responder a una decisión previa. El profesor Ribot se hace eco de la confusión que existe en la historiografía (que ha recogido diversos días de junio y julio como fechas en la que se celebraría el Consejo de Estado en la que se fijó la postura española), apuntando en su texto a que la mayor probabi- 
lidad correspondería al día 8 de junio ${ }^{98}$. A nuestro parecer dicha fecha es bastante consistente tanto por los argumentos aportados como porque, en cualquier caso, tuvo que ser anterior al 14 de junio, ya que con dicha fecha Carlos II se dirige al Papa, comunicando la decisión como tomada ${ }^{99}$.

Por tanto, entre la fecha del Consejo de Estado y la de la carta al Papa, el 14, se celebra la reunión extraordinaria del día 12 sobre el asunto del Darién. En tal contexto nos podemos explicar mejor las dudas de Carlos II y su consulta sobre la conveniencia de enviar la expedición de Navarrete a Indias. Esto también nos reafirma en nuestra opinión sobre que debe ser contemplada en conjunto con la sucesión española. Hemos podido ver los argumentos: el peligro para la religión y el comercio, la reputación en juego o que, en cualquier caso, tampoco serían medios suficientes para otros fines. También nos gustaría introducir otra consideración. Si a principios de junio de 1700, la mayoría del Consejo de Estado era partidaria de la opción de un testamento francés, en realidad la urgencia en otros frentes, quedaba bastante aminorada y parece muy lógico que España intentara hacer una demostración de fuerza y de su determinación de defensa que, significativamente, se hace contra unos súbditos de Guillermo III.

Además, en su carta al Papa, Carlos II expresaba su preocupación por que la partición acordada incluyera cesiones territoriales a las potencias marítimas en América, que no estaban recogidas en el tratado de partición ${ }^{100}$. Este temor puede encontrar su fundamento en el episodio escocés, pero también encontrar un argumento respecto a la decisión de un testamento francés ya que, en caso de tener que defenderse de una agresión angloholandesa en Indias, un heredero austriaco no aportaba ninguna solución.

Por último, también queremos remarcar la coincidencia de los tiempos: la llegada de las noticias sobre los primeros combates coincidieron con la difusión de las conversaciones de la Haya sobre la sucesión de la monarquía española, las de la segunda ocupación escocesa fueron simultáneas a la firma del Tratado de Partición de Londres y la salida de la flota de Navarrete se produjo en plena crisis diplomática que derivaría en el definitivo testamento de Carlos II. De todo este asunto se pueden extraer algunas consecuencias como las dificultades de Guillermo III para controlar las acciones de sus súbditos o la solidez del dominio español en Indias, que pareció capaz, casi exclusivamente con sus propios medios, de conjurar esta amenaza; pero además que este incidente, junto con la ruptura diplomática tratada, parecía haber tenido la potencialidad suficiente como para haber provocado una guerra con Inglaterra ${ }^{101}$.

98 RIBOT, 2010, 104/105.

99 El texto de la carta en LEGRELLE, 1890, 355/356.

100 Respecto al tratado de partición, la versión en inglés está recogida en GRIMBLOT, 1848, 493/506, y la versión en francés en LEGRELLE, 1890, 690/706.

101 Ésta era, al menos, la opinión de Guillermo III: «Edinburg, Oct. 30. (...) His Majesty tells them, that it was with regret, that he could not yield unto the pressing desires of all his Ministers about the affairs of 


\section{BIBLIOGRAFÍA}

ALLAN, David, «Manners and Mustard: Ideas of Political Decline in Sixteenth-Century Scotland», Comparative Studies in Society and History, 37 (Cambrigde, 1995): 242/263.

ARMITAGE, David, ««The Projecting Age»: William Paterson and the Bank of England», History Today, 44 (Londres, 1994): 5/10.

- «The Scottish Vision of Empire: Intellectual Origins of the Darien Venture», en John Robertson (ed.), A Union for Empire: Political Thought and the Union of 1707, Cambridge, Cambridge University Press, 1995, 97/118.

- «A Patriot for Whom? The Afterlives of Bolingbroke's Patriot King", Journal of British Studies, vol. 36/4 (Cambrigde, 1997): 397/418.

BARBOUR, James S., A history of William Paterson and the Darien Company, Edimburgo, W. Blackwood and sons, 1907.

BÉLY, Lucien, «La diplomatie européenne et les partages de l'empire espagnol», en Antonio Álvarez-Ossorio, Bernardo J. García García y Virginia León (eds.), La pérdida de Europa. La guerra de Sucesión por la Monarquía de España, Madrid, Fundación Carlos de Amberes, 2007, 631/652.

BERGIN, John, «The Quaker Lobby and Its Influence on Irish Legislation, 1692-1705», EighteenthCentury Ireland / Iris an dá chultúr, 19 (Dublín, 2004): 9/36.

BINGHAM, Hiram, «Virginia Letters on the Scots Darien Colony, 1699», The American Historical Review, 10/4 (Bloomington, 1905): 812/815.

BURTON, Ivor F., RILEY Patrick, W. J. y ROWLANDS, Edward, Political Parties in the Reign of William III and Anne: The Evidence of Division Lists, Londres, Athlone Press, 1968.

CHILDS, John, The British Army of William III, 1689-1702, Manchester, Manchester University Press, 1987.

CHREE O'MALLEY, Leslie, «The Whig Prince: Prince Rupert and the Court vs. Country Factions during the Reign of Charles II», Albion: A Quarterly Journal Concerned with British Studies, 8/4 (Boone, 1976): 333/350.

CHRISTIE, Ian R,. «The Tory Party, Jacobitism and the 'Forty-Five: A Note», The Historical Journal, 30/4 (Oxford, 1987): 921-931.

COWARD, Barry, The Stuart Age, England, 1603-1714, Londres, Longman, 2003.

CRUICKSHANKS Eveline, y ERSKINE-HILL, Howard, «The Waltham Black Act and Jacobitism», Journal of British Studies, 24/3 (Cambrigde, 1985): 358-365.

DE BAVIERA Adalberto, y Gabriel MAURA GAMAZO, Documentos inéditos referentes a las postrimerías de la Casa de Austria en España, vol. Il (1698-1703), Madrid, RAH, 2004.

DE BERNARDO ARES, José Manuel, «Tres años estelares de política colonial borbónica (17011703)», Cuadernos de Historia de España, 80 (Buenos Aires, 2006): 171-196.

DOBSON, David, «Seventeenth-Century Scottish Communities in the Americas», en Alexia Grosjean y Steve Murdoch (eds.), Scottish Communities Abroad in the Early Modern Period, Boston, Brill, 2005, 114/122.

DOWNIE, Allan J., «The Commission of Public Accounts and the Formation of the Country Party», The English Historical Review, vol. 91/358 (Oxford, 1976): 33/51.

DOYLE, Thomas, "Jacobitism, Catholicism and the Irish Protestant Elite, 1700-1710", EighteenthCentury Ireland / Iris an dá chultúr, 12 (Dublín, 1997): 28/59.

Darien, because it would have drawn the Nation into a War, in which he could expect no assistance, and exhort them to give the supply necessary for maintaining the Nation in its present happy settlement", Post Man and the Historical Account, 2/XI/1700, nº 825. 
FOORD, Archibald S., «The Waning of «The Influence of the Crown»», The English Historical Review, Vol. 62/245 (1947):484-507

FORRESTER, Andrew, The man who saw the future: [William Paterson's vision of free trade], Londres, Thomson-Texere, 2004.

GRIMBLOT, Paul (Ed.), Letters of William III and Louis XIV and of their ministers; illustrative of the domestic and foreign politics of England, from the Peace of Ryswick to the accession of Philip V of Spain. 1697 to 1700, vol. II, Londres, Longman, 1848.

HARRIS, Tim, Politics under the later Stuarts: Party Conflict in a Divided Society 1660-1715, Londres, Longman, 1993.

HART, Francis R., The Disaster of Darien: The Story of the Scots Settlement and the Causes of its Failure, 1699-1701, Londres, Constable \& Co., 1930.

HAYTON, David W., «The «Country» Interest and the Party System 1689-c.1720», en Clyve Jones (ed.), Party and Management in Parliament, 1660-1784, Leicester, Leicester University Press, 1984, 37/85.

- «The Country Party in the House of Commons 1698-1699: a Forecast of the Opposition to a Standing Army? », Parliamentary History, 6/1 (Londres, 1987): 141/163.

HIDALGO, Dennis R., «To Get Rich for Our Homeland: The Company of Scotland and the Colonization of the Isthmus of Darien», Colonial Latin American Historical Review, 10/3 (Albuquerque, 2001): 311/350.

HILL BURTON, John, The Darien Papers: Being a Selection of Original Letters and Official Documents Relating to the Establishment of a Colony at Darien by the Company of Scotland Trading to Africa and the Indies, 1695-1700, Edimburgo, Thomas Constable, 1849.

HOLMES, Geoffrey, «Tom Wharton and the Whig Junto: Party Leadership in Late Stuart England», Parliamentary History, 28 (Londres, 2009):100/114.

HOPPIT, Julian, A Land of Liberty? England, 1689-1727, Oxford, Clarendon Press, 2000.

HORWITZ, Henry, «Parties, Connections, and Parliamentary Politics, 1689-1714: Review and Revision", Journal of British Studies, 6/1 (Cambrigde, 1966): 45/69.

- Revolution Politicks. The Career of Daniel Finch, Second Earl of Nottingham, 1647-1730, Cambridge, Cambridge University Press, 1968.

- «The Structure of Parliamentary Politics», en Geoffrey Holmes (ed.), Britain After the Glorious Revolution, New York, St. Martin's Press, 1969, 96/115.

— «The General Election of 1690», Journal of British Studies, 10 (Cambrigde, 1971): 77/89.

- «Parliament and the Glorious Revolution,» Bulletin of the Institute of Historical Research, 67 (Londres, 1974): 36/53.

HUMPHREY Shawn, y HANSEN, Bradley A., «Constraining the state's ability to employ force: the standing army debates, 1697-99", Journal of Institutional Economics, 6 (Cambridge, 2010), 243/259.

JONES, Clyve, «Whigs, Jacobites and Charles Spencer, Third Earl of Sunderland», The English Historical Review, 109/430 (Oxford, 1994): 52/73.

KEITH, Theodora, «The Economic Causes for the Scottish Union», English Historical Review, 24 (Oxford, 1909): 44/60.

KENYON, John P., «The Earl of Sunderland and the King's Administration, 1693-1695», The English Historical Review, 71/281 (Oxford, 1956): 576/602.

LEGRELLE, Arsène, La diplomatie française et la succession d'Espagne. Volume 2 : Le deuxième traité de partage (1697-1699), París, F. Pichon Gand : Dullé-Plus, 1889.

- La diplomatie française et la succession d'Espagne. Volume 3 : Le troisième traité de partage (1699-1700), París, F. Pichon Gand: Dullé-Plus, 1890.

LEMMAN, Bruce, The Jacobite Risings in Britain 1689-1746, Aberdeen, Scottish Cultural Press, 1995. 
LEVACK, Brian P., The Formation of the British State: England, Scotland, and the. Union, 16031707, Oxford, Clarendon Press, 1987.

LÓPEZ CAMPILLO, Rosa M., Daniel Defoe y La Guerra de Sucesión Española, tesis doctoral, Departamento de Filología Moderna, Universidad de Castilla La Mancha (Ciudad Real, 2008).

Lord MAHON (ed.), Spain under Charles the second, or Extracts from the correspondance of the Hon. Alexander Stanhope, British Minister at Madrid, Londres, John Murray, 1744.

McJIMSEY, Robert D., «A Country Divided? English Politics and the Nine Years' War», Albion: A Quarterly Journal Concerned with British Studies, vol. 23/1 (Boone, 1991): 61/74.

- "Crisis Management: Parliament and Political Stability, 1692-1719", Albion: A Quarterly Journal Concerned with British Studies, vol. 31/4 (Boone, 1999): 559/588.

McPHAIL, Bridget, «Through a Glass, Darkly: Scots and Indians Converge at Darien», EighteenthCentury Life, 18 (Durham, 1994): 129/147.

MONOD, Paul, «Jacobitism and Country Principles in the Reign of William III», The Historical Journal, 30/2 (Cambrigde, 1987): 289/310.

NAAMANI TARKOW Israel, «The Significance of the Act of Settlement in the Evolution of English Democracy», Political Science Quarterly, 58/4 (Oxford, 1943), 537/561.

ONNEKINK, David, «The Anglo-Dutch Favourite: The Career of Hans Willem Bentinck, 1st Earl of Portland (1649-1709)", Facultad de Letras de la Universidad de Utrecht, tesis doctoral (Utrecht, 2004).

O'SULLIVAN, Harold, «The Jacobite Ascendancy and Williamite Revolution and Confiscations in County Louth 1684-1701 ", Journal of the County Louth, Archaeological and Historical Society, 22/4 (Dundalk, 1992): 430/445.

OZANAM, Didier, les diplomates espagnols du XVIII siècle. Introduction et repertiore biographique, 1700-1708, Madrid, Casa de Velazquez, 1998.

PIQUERAS CÉSPEDES, Ricardo, «Episodios de hambre urbana colonial: las hambrunas de La Isabela (1494), Santa María La Antigua del Darién (1514) y Santa María del Buen Aire (1536)", en Boletín americanista, 48 (Barcelona, 1998): 211/223.

PRATT INSH, George, «The Founding of the Company of Scotland Trading to Africa and the Indies", The Scottish Historical Review, 21 (Edimburgo, 1924): 288/295.

- Darien Shipping Papers Relating to the Ships and Voyages of the Company of Scotland Trading to Africa and the Indies, 1696-1707, Edimburgo, Scottish Historical Association, 1924.

- «The founders of the Company of Scotland», Scottish historical review, vol. 25 (Edimburgo, 1928): $241 / 254$

- The Company of Scotland Trading to Africa and the Indies, Londres, C. Scribner's sons, 1932.

- The Darien scheme, Londres, Historical Association, 1947.

PREBBLE, John, The Darien Disaster: A Scots Colony in the New World, 1698-1700, New York, Holt, Rinehart and Winston, 1969.

REITAN, Earl A., «From Revenue to Civil List, 1689-1702: The Revolution Settlement and the 'Mixed and Balanced' Constitution», The Historical Journal, vol. 13/4 (Oxford, 1970): 571/588.

RILEY, Patrick W. J., King William and the Scottish politicians, Edimburgo, John Donald, 1979.

RUBINI, Dennis, Court and Country, 1688-1702, Londres, Rupert Hart-Davis, 1968.

- «Party and the Augustan Constitution, 1694-1716: Politics and the Power of the Executive», Albion: A Quarterly Journal Concerned with British Studies, vol. 10/3 (Boone, 1978): 193/208.

SCHWOERER, Lois G., «The Literature of the Standing Army Controversy, 1697-1699», Huntington Library Quarterly, 28/3 (Berkeley, 1965): 187/212.

— «he Role of King William III of England in the Standing Army Controversy, 1697-1699», Journal of British Studies, 5/2 (Cambrigde, 1966): 74/94.

SCOTT, John y JOHNSTON, George P., A bibliography of printed documents and books relating to the Darien company, Edimburgo, Edinburgh Bibliographical Society, 1906. 
SMOUT, T. C., «The Anglo-Scottish Union of 1707. I. The Economic Background», The Economic History Review, 16/3 (Glasgow, 1964): 455/467.

SNYDER, Henry, «Godolphin and Harley: A Study of Their Partnership in Politics», Huntington Library Quarterly, 30/3 (Berkeley, 1967): 241/271.

- «Party Configurations in the Early Eighteenth Century House of Commons», Bulletin of the Institute of Historical Research, vol. 54 (Londres, 1972), págs 38/73.

STEEL, W. A., «William Paterson», The English Historical Review, 11/42 (Oxford, 1896): 260/281.

STEELE, Ian K., «The Board of Trade, The Quakers, and Resumption of Colonial Charters, 16991702», The William and Mary Quarterly, 23/4 (Williamsburg, 1966): 596/619.

STORRS, Christopher, «Disaster at Darien (1698-1700)? The persistence of Spanish imperial power on the eve of the demise of the Spanish Habsburgs", European history quarterly, 29/1 (Londres, 1999): 5/38.

- The Resilience of the Spanish Monarchy 1665-1700, Oxford, Oxford University Press, 2006.

STORRS, Christopher, «The Union of 1707 and the War of the Spanish Succession», The Scottish Historical Review, 87 (Edimburgo, 2008): 31/44.

SZECHI, Daniel, «The Jacobite Revolution Settlement, 1689-1696», The English Historical Review, 108/428 (Oxford, 1993): 610/628.

THOMSON, M. A., "Louis XIV and the Origins of the War of the Spanish Succession», Transactions of the Royal Historical Society,. 4 (Londres, 1954): 111-134.

TROOST, Wouter, William III the Stadholder-King: A Political Biography, Londres, Ashgate, 2005.

WALCOTT, Robert, English Politics in the Early Eighteenth Century, Cambridge, Harvard University Press, 1956.

WALLACE, Dr. F. R. S, «Part of a Journal Kept from Scotland to New Caledonia in Darien, with a Short Account of That Country", Philosophical Transactions (1683-1775), 22 (Londres, 1700/1701): 536/543.

WARD, Christopher, «Historical Writing on Colonial Panama», The Hispanic American Historical Review, 69/4 (Durham, 1989): 691/713.

WATT, Douglas, «The Management of Capital by The Company of Scotland 1696-1707», Journal of Scottish Historical Studies, 25 (Edimburgo, 2005): 97/118. 